\title{
A Panel Data Analysis of Stock Returns and Accounting Information in Indian Paint Industry
}

\author{
Pradeep Kumar Rangi ${ }^{1}$ \& P. S. Aithal ${ }^{2}$ \\ ${ }^{1}$ Research Scholar, College of Management \& Commerce, Srinivas University, Mangalore, \\ India \\ OrcidID: 0000-0002-2052-9054; E-mail: pradeep.rangi@gmail.com \\ ${ }^{2}$ Professor, College of Management \& Commerce, Srinivas University, Mangalore, India \\ OrcidID: 0000-0002-4691-8736; E-mail: psaithal@gmail.com
}

Area/Section: Business Management.

Type of the Paper: Empirical Research.

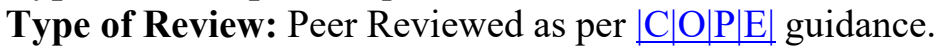

Indexed in: OpenAIRE.

DOI: $\underline{\text { http://doi.org/10.5281/zenodo.4496890 }}$

Google Scholar Citation: IJMTS.

\section{How to Cite this Paper:}

Rangi, Pradeep Kumar, \& Aithal, P. S., (2021). A Panel Data Analysis of Stock Returns and Accounting Information in Indian Paint Industry. International Journal of Management, Technology, and Social Sciences (IJMTS), 6(1), 32-40. DOI: http://doi.org/10.5281/zenodo.4496890.

International Journal of Management, Technology, and Social Sciences (IJMTS) A Refereed International Journal of Srinivas University, India.

(C) With Author.

CrossRef DOI: https://doi.org/10.47992/IJMTS.2581.6012.0128

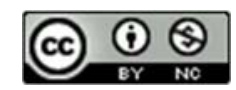

This work is licensed under a Creative Commons Attribution-Non-Commercial 4.0 International License subject to proper citation to the publication source of the work.

Disclaimer: The scholarly papers as reviewed and published by the Srinivas Publications (S.P.), India are the views and opinions of their respective authors and are not the views or opinions of the SP. The SP disclaims of any harm or loss caused due to the published content to any party. 


\title{
A Panel Data Analysis of Stock Returns and Accounting Information in Indian Paint Industry
}

\author{
Pradeep Kumar Rangi ${ }^{1} \&$ P. S. Aithal ${ }^{2}$ \\ ${ }^{1}$ Research Scholar, College of Management \& Commerce, Srinivas University, Mangalore, \\ India \\ OrcidID: 0000-0002-2052-9054; E-mail: pradeep.rangi@gmail.com \\ ${ }^{2}$ Professor, College of Management \& Commerce, Srinivas University, Mangalore, India \\ OrcidID: 0000-0002-4691-8736; E-mail: psaithal@gmail.com
}

\begin{abstract}
The accounting ratios and published financial information serve as a critical tool for investors, creditors, and other stakeholders to ascertain companies' profitability, control, and financial status, which may significantly impact the Stock returns and performance on exchanges. This paper aims to examine whether crucial accounting information affects the price of paint companies in India. In this paper, nine-years (2012-2020) accounting ratios such as returns on asset, equity, and cash cycles for the five listed paint companies in India as explanatory (independent) variables to estimate stock returns. Secondary data is collected chronologically and at a regular yearly frequency. Variables data are derived from the company's financial statements, Stock Exchange and related website. The study aims to assess and elaborate these accounting ratios effectiveness to substantiate the stock returns of these listed companies. The study uses three-panel data models, the pooled OLS, fixed and random effects, to assess stock returns for the cross-sectional data of these five paint companies. This research indicates that accounting information is significant and positively affects the price of Paint company stock returns on the stock exchange. Both Fixed and Random effect model found to fit the data, significance level of 0.05 (Fixed (FE) at $\mathrm{F}=6.3625, \mathrm{p}<0.000$ and $\mathrm{R}^{2}$ of 0.5462 , i.e., fixed effect elaborates for about $55 \%$ of the return variance. Random effect at $\mathrm{F}=10.8647$ and $\mathrm{p}<0.000$ and $\mathrm{R}^{2}$ of 0.4429 , i.e., elaborates for about $44 \%$ of stock return variance. Based on the Hausman data test alternative hypothesis is found to be consistent and therefore Random Effect (RE) model is being used to conclude the findings. The paper's fundamental limitation includes use of limited regressors, companies, and time period. A further qualitative analysis together with other accounting performance indicators as regressors may be included in future studies. These ratios include interest coverage, debt ratios, effective tax rates, asset turnover ratios, dividend distribution ratios, sustainable growth, and top line revenue growth.
\end{abstract}

Keywords: Panel data, Paint industry, Hausman, Stock Returns, Accounting Ratios

\section{INTRODUCTION :}

The domestic Indian paint industry consisting of both decorative (examples include interior wall, wood finish, premiers, and putti) and industrial paint (examples include automotive, marine, and packaging floor) categories is estimated at ₹50K Crores. The split of market share between decorative paints and industrial paint is about 75 and 25 percent, respectively (as per Asian Paint annual report 2019-20). The annual report also highlights that the unorganized industry is about 30 to 35 percent of the market share. Five listed entities from the paint industry in India are assessed for this research work. These companies are Asian (INE021A01026), Berger (INE463A01038), Shalimar (INE849C01026), Nobel (INE133A01011), Nerolac (INE531A01024) [1]. This paper aims to assess the capability of ROA, ROE, and Cash Conversion cycle-related information to explain the stock returns and aids the process of equity valuation only and no part of the study should be construed as investment advice or investment recommendation.

Accounting ratios are the numerical values derived from the entity's income and expenditure statements, position statement or balance sheet, cash flow statement, notes to the accounts, and another 
public filing bu entities in its ordinary business course. Accounting pieces of information are critical to obtaining meaningful statistics about the firm. Traditionally, earnings, profitability and return ratios were the critical accounting statement focused information for assessing the profitability and stock returns. Stock price volatility behavior related discussions accelerated by Markowitz's (1952 and 1959), Sharpe's (1964) and Lintner's (1965) study by recognizing the need to analyze and quantify risk as a catalyst for stock returns [2]-[5]. The financial information and statistics on the company's financial statements can facilitate a quantitative study to examine sustainability, leverage, efficiency, profits, competitiveness, return on capital, and company valuation. The explanation regarding stock return and its volatility in the financial market or stock exchange can be explained through the conflicts in perception over whether the business is operating efficiently and the company's future earning potential and several other quantitative and qualitative factors. Accounting ratios serve as a powerful tool to validate an investor's perceptions by looking at the business's fundamental strength, i.e., operating efficiencies, liquidity position, level of leverage, profitability, and market valuation [6], [7]. Accounting measures often provide and utilized for predictive purposes, either indirectly or specifically. It is evident from the research reviewed and practical illustration of industry reports that they are believed to be strong measures of the company's financial and market results and characteristics and that they can be used to estimate potential performance and features [7]-[9]. This paper aims to examine whether crucial accounting information affects the price of paint companies in India. In this paper, nine-years (20122020) accounting ratios such as returns on asset, equity, and cash cycles for the five listed paint companies in India as explanatory (independent) variables to estimate stock returns. For this study regressors related data is obtained from the morning star website and stock returns data is obtained from yahoo finance.

Return on Assets (ROA) provides measures the profitability of an entity concerning its total assets. Therefore, the provides a good indication as to how effectively the economic resources of entity are deployed by management, this is achieved by comparing net income against resources invested or employed in entities assets. A sustainable high return rate suggests management strength and could provide a strong basis for making investment decisions. The ratio offers a good measure of a company's performance between accounting periods and against other companies operating in a similar environment, scale, and industry. Typically, a lower ROA indicates that a company is an asset-intensive company, e.g., refineries and airlines, and similarly, the higher the return on assets suggests an assetlight company. However, exceptions may result from each company's unique characteristics, profitability, and scale at which such business is operating.

Return on Equity (ROE) is a quantitative means of assessing the strength of a company to generate profits. It is pegging net income against equity. For this paper, these values are obtained from the morning star website. ROE brings two foundational components of financial information, i.e., performance (profit and loss) and position (i.e., Balance Sheet) as net income pegged against shareholders' equity. The resultant information represents the total return on equity capital and reflects company's ability to generate profit from company assets or measures the profits generated against each rupee of shareholders' equity. A significant ROE above companies or industry cost of capital and upward trend may indicate that the firm is efficient and skilled in generating shareholder returns and has robust capital allocation practices, thereby realizing the importance of reinvesting its earnings in productive and high-quality assets. However, caution may be required to apply ratios in the case companies in its early stage where the capital requirement is high and need deep funding to bring the operation to be scalable, and reading of annual reports and management commentary may provide supplementary information to the stakeholders.

Cash Cycles or conversion cycle (CC) provides a metrics to measure days a firm or business take to convert its resources invested in stock (or input materials) to cash or bank balance. CC takes into consideration three elements, i.e., outstanding payable, sales exceptional, and inventory i.e., outstanding inventory day, plus, outstanding sales day, minus, payable day outstanding. This ratio therefore indicates the company's efficiency in managing its working capital on a business as usual basis. The shorter the cycle, the company is more efficient at selling stocks and realizing receivables.

Panel data analysis for all the five paint companies (referred above) is undertaken for the period of 2012-2020. Panel data may be stated as repeated observations on the same companies (e.g., five paint 
companies) of cross-section units in different periods, e.g., 2012-2020. Panel data models permits for taking heterogeneity into account (explicitly) [10], [11].

\section{LITERATURE OVERVIEW :}

Researchers and industry practitioners have significantly impacted this direction and have suggested several new aspects of the stock returns using multiple regressors and its relationship with accounting information — some of the scholarly published papers in this area is outlined in Table 1 .

Table 1: Related publications on Accounting information and ratios and stock return and volatility by different researchers

\begin{tabular}{|c|c|c|}
\hline S. No. & Focus Area & References \\
\hline 1 & $\begin{array}{l}\text { Paper describes the case study of the writing business based on a recently } \\
\text { developed company research system. The study also proposes a case study } \\
\text { approach for beginners and budding scholars for management analysis as a } \\
\text { starting step in scholarly research. }\end{array}$ & [9], [25] \\
\hline 2 & $\begin{array}{l}\text { Many regression approaches employed by EPS \& Dividend indicates a } \\
\text { significant association. Net income and Shari'ah-Compliance are not found } \\
\text { to be substantial towards stock market fluctuations. }\end{array}$ & [12] \\
\hline 3 & $\begin{array}{l}\text { Paper explores the capacity of conventional and contemporary success } \\
\text { metrics to interpret earnings control. Results suggest that the relationship } \\
\text { between (ROA) and earnings control is both important and inverse. }\end{array}$ & [13] \\
\hline 4 & $\begin{array}{l}\text { A strong association between each stock and index rather than inter-stock } \\
\text { dependency is noted in the study. }\end{array}$ & [14] \\
\hline 5 & $\begin{array}{l}\text { Examined the critical success metrics of net profits and free cash flow FCF } \\
\text { to assess whether EVA performs differently than other performance } \\
\text { measures. EVA has low predictability for results, and Free Cash Flow has } \\
\text { marginally better predictability than other metrics. }\end{array}$ & [15] \\
\hline 6 & $\begin{array}{l}\text { The EPS, DPS, ROE and ROCE ratios are analyzed to assess its impact on } \\
\text { share price. EPS and DPS are the ratios representing the success of the } \\
\text { chemical industry in India's national stock exchange. }\end{array}$ & [16] \\
\hline 7 & $\begin{array}{l}\text { Paper discussed expanding the Z-score model to predict UK companies' } \\
\text { health; using discriminatory regression and output ratios, assess which rates } \\
\text { are statistically crucial in predicting UK companies' health from } 2000 \text { to } \\
\text { 2013. The strength of the model was } 82.9 \text { percent, according to the Z-score } \\
\text { model. }\end{array}$ & [17] \\
\hline 8 & $\begin{array}{l}\text { For the purpose of studying growth convergence, panel data analysis and } \\
\text { methods proposed and propagated. }\end{array}$ & [18] \\
\hline 9 & $\begin{array}{l}\text { Panel data estimations are used to determine the relationship between } \\
\text { accounting variables and stock returns. }\end{array}$ & [19] \\
\hline 10 & $\begin{array}{l}\text { Two-dimensional classification for ratios proposed. Level one operations } \\
\text { ratios, level two financial leverage ratios, level three stock market-related } \\
\text { ratios, and finally fourth level i.e. functional ratios. }\end{array}$ & {$[20]$} \\
\hline 11 & $\begin{array}{l}\text { Multiple regressions used to discuss relationship between ratios and stock } \\
\text { prices. Study utilized finance ratio as a basis to assess and substantiate risk- } \\
\text { return of stock. }\end{array}$ & [21] \\
\hline
\end{tabular}




\begin{tabular}{|l|l|l|}
\hline 12 & $\begin{array}{l}\text { Paper examines the volatility and change in earnings and income for banks } \\
\text { and its impact on share price }\end{array}$ & {$[22]$} \\
\hline 13 & $\begin{array}{l}\text { The influence of the cash cycle is widespread across sectors, remains distinct } \\
\text { from established return predictors except for high capitalization stocks, and } \\
\text { cannot be clarified by the possibility of intermediary leverage. }\end{array}$ & {$[23]$} \\
\hline 14 & $\begin{array}{l}\text { Negative relationship between cash cycle and profitability demonstrated for } \\
\text { the companies with exceptions noticed in consumer stocks }\end{array}$ & {$[24]$} \\
\hline
\end{tabular}

\section{OBJECTIVES OF THE STUDY :}

This paper aims to examine whether crucial accounting information affects the price of paint companies in India. It also includes:

(1) Examine regressors (ROA, ROE and CCC's) ability to predict stock returns.

(2) Examine FE and RE Residual (error term), Actual and Fitted data; and

(3) Perform Hausman test to select appropriate model i.e., FE or RE model for assessment of results.

\section{DATA AND RESEARCH METHEDOLOGY :}

In this paper, nine-years (2012-2020) accounting ratios such as returns on asset, equity, and cash cycles for the five listed paint companies in India as explanatory (independent) variables to estimate stock returns i.e., Stock Returns, a Panel data analysis for Asian (INE021A01026), Berger (INE463A01038), Shalimar (INE849C01026), Nobel (INE133A01011), Nerolac (INE531A01024) is undertaken for the period of 2012-2020. For this study regressor and stock return related data is obtained company's financial statements, Stock Exchange and related websites e.g., money control, yahoo finance and morning star. The stock prices (i.e., Average stock price for the year) for each stock is calculated by taking an average of year opening stock price and years closing stock price for each year. Stock returns for the year are calculated by author using average price of " $t$ " year, minus, "t-1", divided by Average price of year "t-1". The accounting ratios used in the paper are directly obtained from the morning star website and cross checked by manual calculations from respective published reports on company websites.

A simplified panel data regression model may be represented as $\mathbf{Y}_{i t}=\boldsymbol{A}_{\boldsymbol{i}}+\boldsymbol{B} \boldsymbol{x}_{\boldsymbol{i t}}+\boldsymbol{E}_{\boldsymbol{i t}}$.

In the above regression model, ' $\mathrm{Y}$ ' indicates dependent (or predicted) variable, ' $\mathrm{X}$ ' is explanatory variables. Coefficients (for independent Variable and constant) in the model is indicated by ' $A$ ' and ' $B$ ' respectively, ' $i$ ' and ' $\mathrm{t}$ ' are individual elements and time, respectively. In this study, an individual element is a cross-sectional contribution from paint companies. Time refers to as time series in a sequence for which data has been observed. In the FE model assumes that $E_{i t}$ demonstrates nonstochastic behavior over ' $\mathrm{i}$ ' and ' $\mathrm{t}$ ', which is assumed as stochastic behavior in RE model.

The pooled OLS model assumes homogeneity, i.e., it does not differentiate between panel sections; therefore, miss to consider the unique characteristics of each element within the panel data set and on overall basis over the time. The fixed-effect model (FE) allows for heterogeneity or unique characteristic among cross-sections with allowing for each to have its constant or intercept, however time time-invariant, i.e., in the equation above 'A' changes as per elements but stays invariant from a time perspective. However, the random Effect (RE) model has a common 'A,' i.e., the mean of all the cross-sectional 'A's. In the RE model, 'E' changes in a stochastic manner. RE assumes that individual specific effects aren't correlated with independent variables. Distribution is all normal with zero mean. The Hausman test (1978) is considered as a suitable statistical test by looking at the correlation of unique erros with regressors. It aids to determine appropriateness of FE or RE's model for the the given case. H0, i.e., if $\mathrm{p}>0.05$ select Random Effect Model alternatively select FE.

\section{RESULTS AND DISCUSSION :}

Pooled-OLS model found to fit the data significantly at $.05(\mathrm{~F}=10.8647, \mathrm{p}<0.000) . \mathrm{R}^{2}$ of 0.4429 elaborates for about $44 \%$ of the return variance. Based on the probability values, Return on Equity 
(ROE) and Cash Cycle (CC) are statistically significant while Return on Assets (ROA) is not. One unit increase in ROE contributes increase in stock return by 0.0121 . One unit increase in CC contributes increase in 0.0028 in stock return, this positive relationship indicates that there is a need to perform a further analysis (including qualitative) of the variables and incentive and channel management policies and practices. Conversely, a 1 unit increase in ROA results in decrease in stock return of 0.0130 , indicating further analysis is required by including other independet variables. Although Pooled OLS model fits the data well it does not distinguish between the five paint companies, further analysis using FE and RE model is warranted as simple pooled OLS neglects both cross section and time series characteristics of sampled data. Both Fixed and Random effect model found to fit the data, significance level of 0.05 (Fixed (FE) at $\mathrm{F}=6.3625, \mathrm{p}<0.000$ and $\mathrm{R}^{2}$ of 0.5462 , i.e., fixed effect elaborates for about $55 \%$ of the return variance. Random effect at $\mathrm{F}=10.8647$ and $\mathrm{p}<0.000$ and $\mathrm{R}^{2}$ of 0.4429 , i.e., elaborates for about $44 \%$ of stock return variance. (refer Figure 1 and Table 2 for more details)
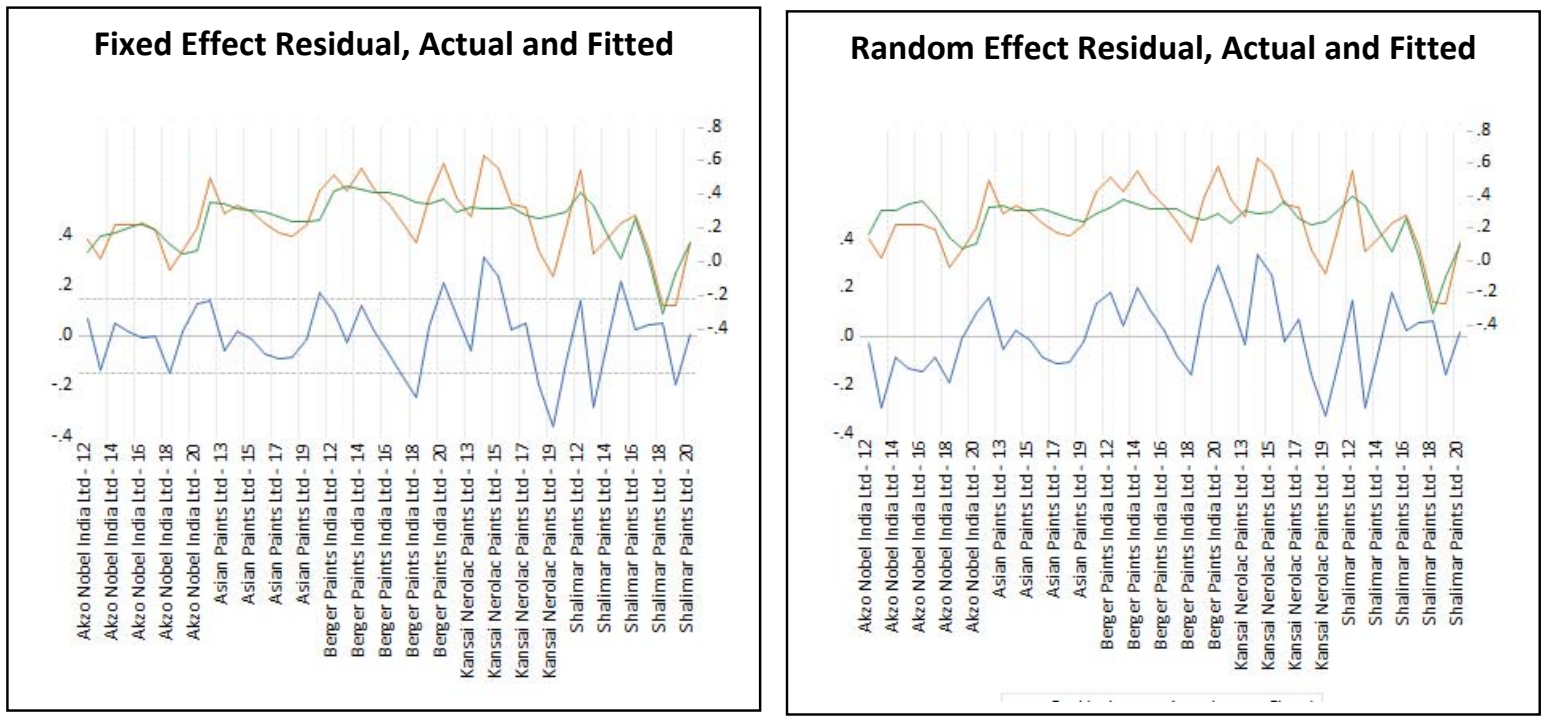

Source : Generated by author using Eview software

Fig. 1: Fixed Effect and Random effect Residual (error term), Actual and Fitted

The Idiosyncratic random Rho value for Random Effect model is 1 indicating lower pooling effect and regression is panel data proper. Though Akaike, Schwarz and Hannan-Quinn criterion indicate relative strength of model, in this study these are measured below 5 i.e. AIC (-0.8026), SC (-0.4814) and HQC $(-0.6829)$, indicating the robustness of the FE model. The results for all the three panel data models discussed above are summarized in Table 2 below.

Table 2 : Regression Results - Pooled OLS, Fixed Effect Model and Random Effect Model

\begin{tabular}{|l|l|l|l|l|}
\hline Variables & Measures & Pooled OLS & $\begin{array}{l}\text { Fixed Effect } \\
\text { Model }\end{array}$ & $\begin{array}{l}\text { Random } \\
\text { Effect } \\
\text { Model }\end{array}$ \\
\hline \multirow{4}{*}{ Intercept } & Coefficient & -0.0084 & 0.1163 & -0.0084 \\
\cline { 2 - 5 } & SE & 0.0778 & 0.1075 & 0.0739 \\
\cline { 2 - 5 } & $\mathrm{t}$ Stat & -0.1085 & 1.0816 & -0.1142 \\
\cline { 2 - 5 } & Prob. & 0.9141 & 0.2864 & 0.9096 \\
\hline \multirow{3}{*}{ Return on Assets (ROA) } & Coefficient & -0.0130 & -0.0190 & -0.0130 \\
\cline { 2 - 5 } & SE & 0.0080 & 0.0108 & 0.0076 \\
\cline { 2 - 5 } & $\mathrm{t}$ Stat & -1.6241 & -1.7535 & -1.7095 \\
\hline
\end{tabular}




\begin{tabular}{|c|c|c|c|c|}
\hline & Prob. & 0.1120 & $0.0878 * *$ & $0.0949 * *$ \\
\hline \multirow{4}{*}{ Return on Equity (ROE) } & Coefficient & 0.0121 & 0.0139 & 0.0120 \\
\hline & SE & 0.0037 & 0.0041 & 0.0035 \\
\hline & t Stat & 3.2788 & 3.3699 & 3.4511 \\
\hline & Prob. & $0.0021^{*}$ & $0.0018^{*}$ & $0.0013^{*}$ \\
\hline \multirow{4}{*}{$\begin{array}{l}\text { Cash Conversion Cycle } \\
\text { (CCE) }\end{array}$} & Coefficient & 0.0028 & 0.0012 & 0.0028 \\
\hline & SE & 0.0011 & 0.0013 & 0.0010 \\
\hline & t Stat & 2.5951 & 0.9750 & 2.7316 \\
\hline & Prob. & $0.0131 *$ & 0.3359 & $0.0093 *$ \\
\hline \multicolumn{2}{|l|}{ F stat } & 10.8647 & 6.3625 & 10.8647 \\
\hline \multicolumn{2}{|l|}{ Prob $(F)$} & $0.0000 *$ & $0.0001 *$ & $0.0000^{*}$ \\
\hline \multicolumn{2}{|l|}{$\mathrm{R}^{2}$} & 0.4429 & 0.5462 & 0.4429 \\
\hline \multirow{2}{*}{\multicolumn{2}{|c|}{$\begin{array}{l}\text { Adj } \mathrm{R}^{2} \\
\text { Idiosyncratic random (Rho) }\end{array}$}} & 0.4021 & 0.4604 & 0.4021 \\
\hline & & & & 1.0000 \\
\hline \multicolumn{2}{|l|}{$\mathrm{AIC}$} & & -0.8026 & \\
\hline \multicolumn{2}{|l|}{$\mathrm{SC}$} & & -0.4814 & \\
\hline \multicolumn{2}{|l|}{ HQC } & & -0.6829 & \\
\hline
\end{tabular}

Source : Calculated by author using Eview software.

*Significant at $5 \%$ and **Significant at $10 \%$

Hausman test results outlined below in Table 3 indicates P-value is not significant $(0.0564$ i.e., $>0.05)$ hence Random model is prefered model in this case.

Table 3: Hausman Test Results

\begin{tabular}{|l|l|l|}
\hline Test Summary & Chi-Sq. Statistic & Prob. \\
\hline $\begin{array}{l}\text { Correlated Random Effects (Random } \\
\text { Cross Sec) }\end{array}$ & 7.54711 & 0.0564 \\
\hline
\end{tabular}

Source : Calculated by author using Eview software

Based on the probability values, Return on Equity (ROE) and Cash Conversion Cycle (CCE) are statistically significant at 5\% while Return on Assets (ROA) is significant at 10\%. One unit increase in ROE contributes increase in stock return by 0.0120 . One unit increase in CCC contributes increase in 0.0028 in stock return, this positive relationship indicates that there is a need to perform a further analysis (including qualitative) of the variables and incentive and channel management policies and practices. Conversely, a 1 unit increase in ROA results in decrease in stock return of -0.0130 , indicating further analysis is required by including other independet variables and or perform qualitative assessment of allocation of resources to assets as a function of profitability. Though the model fits well and values are significant a futher inquiry by including more/ different regressors, companies and increased time-period may result into more suitable model to change in stock returns.

\section{CONCLUSION :}

The selected Random Effect model effect model found to fit the data at the .05 significance level, $\mathrm{F}=10.8647$ and $\mathrm{p}<0.000$ and $\mathrm{R}^{2}$ of 0.4429 , i.e., elaborates for about $44 \%$ of stock return variance. Based on the probability values, Return on Equity (ROE) and Cash Conversion Cycle (CCE) are statistically significant at 5\% while Return on Assets (ROA) is significant at $10 \%$. One unit increase in ROE contributes increase in stock return by 0.0120 . One unit increase in CCC contributes increase in 0.0028 
in stock return, this positive relationship indicates that there is a need to perform a further analysis (including qualitative) of the variables and incentive and channel management policies and practices. Conversely, a 1 unit increase in ROA results in decrease in stock return of 0.0130 , indicating further analysis is required by including other independet variables and or perform qualitative assessment of allocation of resources to assets as a function of profitability. The statastical measurements in this report indicate there is a further opportunity to expand the scope of study to include more regressors, companies, and a longer time period. The paper's fundamental limitation includes use of limited regressors, companies, and time period. A further qualitative analysis together with other accounting performance indicators as regressors may be included in future studies. These ratios include interest coverage, debt ratios, effective tax rates, asset turnover ratios, dividend distribution ratios, sustainable growth, and top line revenue growth.

\section{REFERENCES :}

[1] Ramachandran, J. \& Garg, J. (2019), Asian Paints Limited: Painting History, Indian Institute of Management Bangalore, 749(1), 1-25.

[2] Markowitz, H. (1952), Portfolio Selection, The Journal of Finance, 7(1), 77-91.

[3] Markowitz, H. M. (1959), Portfolio Selection: Efficient Diversification of Investments, Yale University Press, 1(1), 1-368.

[4] Sharpe, W. F. (1964), Capital Asset Prices: A Theory of Market Equilibrium under Conditions of Risk, The Journal of Finance, 19(1), (425-442).

[5] Lintner, J. (1965), The Valuation of Risk Assets and the Selection of Risky Investments in Stock Portfolios and Capital Budgets, The Review of Economics and Statistics, 47(1), $13-37$.

[6] Hatta, A. J. and Bambang Sugeng, D. (2012), The Company Fundamental Factors and Systematic Risk, Journal of Economics, Business, and Accountancy, 15(2), 245 - 256.

[7] Barnes, P. (1987), The Analysis and Use of Financial Ratios: A Review Article, Journal of Business Finance \& Accounting, 14(4), 449-461.

[8] Aithal, P. S. (2017), Industry Analysis - The First Step in Business Management Scholarly Research, International Journal of Case Studies in Business, IT and Education (IJCSBE), 2(1), 113.

[9] Aithal, P. S. (2017), Company Analysis - The Beginning Step for Scholarly Research, International Journal of Case Studies in Business, IT and Education (IJCSBE), 1(1), 1-18.

[10] Gujarati, D. N. Basic Econometrics 4th Edition. 2004.

[11] Baltagi, B. Econometric analysis of panel data. 2005.

[12] Anastassia, A., Firnanti, F. (2014), Factors that affect stock price volatility in non financial public companies, Journal of Business and Accounting, 16(2), 95-102.

[13] Momani, M. A. (2016), The Ability of Traditional and Modern Performance Indicators in Interpreting the Phenomenon of Earnings Management: Evidence Manufacturing Firms in Amman Stock Exchange, Asian Journal of Finance \& Accounting, 8(1), 77-99.

[14] Holthausen, R. W. and Watts, R. L. (2001), The relevance of the value-relevance literature for financial accounting standard setting, Journal of Accounting and Economics, 31(1), 77-104.

[15] Parvaei, A. and Farhadi, S. (2013), The Ability of Explaining and Predicting of Economic Value Added (EVA) versus Net Income (NI), Residual Income (RI) \&amp; Free Cash Flow (FCF) in Tehran Stock Exchange (TSE)., International Journal of Economics and Finance, 5(2), 67-77.

[16] Kiruba, Angelin \& Shanmugam, V. (2020), The Impact of Accounting ratios on Stock Returns: The Case of India's Chemical Industry, Adalya Journal, 9(1), 362-371.

[17] Almamy, J. Aston, J. and Ngwa, L. N. (2016), An evaluation of Altman's Z-score using cash flow ratio to predict corporate failure amid the recent financial crisis: Evidence from the UK, Journal 
of Corporate Finance, 36(1), 278-285.

[18] Islam, N. (1995), Growth empirics: A panel data approach, Quarterly Journal of Economics, 110(4), 1127-1171.

[19] Senyigit, Y. B. and Ag, Y. (2014), Explaining the Cross Section of Stock Returns: A Comparative Study of the United States and Turkey, Procedia - Social and Behavioral Sciences, 109(1), 327 332.

[20] Hilkevics, S. and Semakina, V. (2019), The classification and comparison of business ratios analysis methods, Insights into Regional Development, 1(1), 47-56.

[21] Jermsittiparsert, K. Ambarita, D. E. Mihardjo, L. W. W. and Ghani, E. K. (2019), Risk-return through financial ratios as determinants of stock price: A study from ASEAN region, Journal of Security and Sustainability Issues, 9(1), 199-210.

[22] Rusdiyanto, R. and Narsa, I. M. (2019), The Effects of Earnings Volatility, Net Income and Comprehensive Income on Stock Prices on Banking Companies on the Indonesia Stock Exchange, International Review of Management and Marketing, 9(6), 18-24.

[23] Wang, B. (2019), The cash conversion cycle spread, Journal of Financial Economics, 1(1), 1-57.

[24] Nobanee, H. Abdullatif, M. and Alhajjar, M. (2011), Cash conversion cycle and firm's performance of Japanese firms, Asian Review of Accounting, 19(9), 147-156.

[25] Aithal, P. S. (2017). An effective method of developing business case studies based on company analysis. International Journal of Engineering Research and Modern Education (IJERME), 2(1), $16-27$. 